\title{
Outside-in frontal drill-out technique
}

\section{一より安全で効率的なドリリングを目指して一}

児玉 悟

大分大学医学部耳鼻咽喉科

内視鏡下前頭洞単洞化手術（Draf III型／ endoscopic modified Lothrop procedure: EMLP）は内視 鏡下副鼻腔手術（endoscopic sinus surgery: ESS）のV型に分類されている。難易度の高い手術手技 であるが，学習教材や手術トレーニングコースの充実により，その習得や上達も必ずしも難しいもの ではなくなった。両側の前頭洞単洞化には, 前頭陥凹の内から外へ前頭洞を開放するように前頭洞底 を削除する従来からのDraf III型，inside-outアプローチに加えて，最近では前頭陥凹の外から前頭洞 内に入るoutside-inアプローチも行われるようになった。Outside-inアプローチの特徴は手術前半に, 第1嗅系や鼻骨骨膜といった解剖学的限界を確認し, 広いワーキングスペースを確保しながら, 鼻背 に沿うように前頭陥凹の外から前頭洞に向かってドリリングを行うことにある。基本的なinside-out アプローチをマスターしてから，行うべき手術であると思われるが，前頭陥凹を経由せずに，同部位 を占拠しているような病変に触れることなく，前頭洞・前頭蓋底に到達できる利点がある。

前頭洞単洞化手術の上達のポイントとして, 本手術における内視鏡下の独特の視野に慣れる（視野 を作る）ことが重要であり，ESS I-IV型との大きな違いはドリリングが手術操作の主体となる点であ る。手術解剖を理解し, 良好な視野のもとでランドマークを確認しながら, 決められた手技を決めら れた手順で安全確実に行っていくことは，ESSに限らず他の手術と同様である。いまや内視鏡下拡大 前頭洞手術, 前頭洞単洞化手術は内視鏡下前頭蓋底手術の一部となっているため, 副鼻脭から頭蓋底 ヘステップアップを目指す術者にとってはマスターしたい手術手技である。本セミナーではinsideoutアプローチとoutside-inアプローチの違い, 安全かつ効率的な手術のためのナビゲーションのポイ ントとドリルの上手な使い方について動画を中心に講演します。ESSの初級者から上級者, 頭蓋底手 術の術者の先生方の参考になれば幸甚に存じます。

\section{参考文献）}

1）児玉悟． 拡大前頭洞手術．中川隆之編．内視鏡下鼻副鼻腔 - 頭蓋底手術. 医学書院. 2014, pp110122 .

2）児玉悟. 内視鏡下拡大前頭洞手術 - outside-in approachを中心に一． 頭頸部外科 25: 139-143, 2015.

3）児玉悟，他. Outside-inアプローチの手術手技と症例の検討. 日鼻誌 55: 40-45, 2016.

4）児玉悟. 前頭洞単洞化手術. 耳喉頭頸 89: 318-325, 2017. 


\title{
腫掦性病変に対する経鼻内視鏡下での前頭蓋底切除術および再建術のポイント
}

\author{
花澤 豊行
}

千葉大学大学院医学研究院耳鼻咽喉科・頭頸部腫瘍学

本セミナーでは, 前頭洞に対するOutside-inテクニックの応用編として, 鼻副鼻䏕に発生し頭蓋底 に浸潤した良性もしくは悪性腫瘍に対して行われる経鼻内視鏡下手術について講演する。具体的には 前頭蓋底切除術および硬膜再建術の留意すべき点を, 演者が考える器械の選択・使用方法と切除・再 建に扔ける工夫を中心に解説する。

\section{【前頭蓋底切除において】}

患側の鼻腔に充満し，総鼻道もしくは篩骨洞の天蓋に浸潤した腫瘍に対しては，腫瘍茎を残した分 割切除を施行した上で, 左右の前頭洞底を切除するDraf夕イプIIIを完了させた後に前頭蓋底の切除 に移行する。この際に最も大切なことは，これから切除すべき頭蓋底の骨切りラインをCT所見をも とにプランニングした上で，その全ての切離部位に確実にアクセスできるかを内視鏡下に確認し，ま た切離に使用する機器（ドリル，電気メス，バイポーラなど）が有効に作動するだけの十分なワーキ ングスペースが確保されているかを事前に確かめることである。実際に前頭蓋底の切離を開始すると， 予想以上に鼻孔からの距離は遠く, 器械が上手く働かずに硬膜や脳実質からの出血に難渋させられる ことは少なくない。かと言って術者の都合の良いように（器械が届く範囲に）切離線を変更し，腫瘍 切除の根治性を落とすことは許されない。十分なプランニングと周到な準備をして臨む必要がある。 また, 頭蓋底の切除においては切離する部位に順番が存在する。最初に行うべき切断部位は, 腫崵の 後方の鼻中隔後方断端であり, 蝶形骨洞の前壁も含めて頭蓋底近くまでしっかり切断できていること である。これは頭蓋底の切離が完了した際に，それをすぐに手で感じ取れることと腫瘍を迅速に摘出 できることに繋がる。前頭蓋底は前方から後方に向かい左右を切開して行くが，この操作を行ってお くことで左右の切離線が後方で合流できた瞬間に，腫瘍を含む頭蓋底組織は大きく可動性を带びるよ うになる。頭蓋底切断の完了を感じ取ることができると共に, 鷄冠周囲を処理し, 腫瘍を摘出してし まえば，硬膜や脳実質からの出血にもじっくり対応できることになる。講演では前穊骨動脈の処理や 硬膜からの出血への対応についても解説する。

\section{【硬膜再建において】}

腫瘍切除後の硬膜再建には, 有茎の鼻中隔粘膜弁と大腿筋膜 2 枚を用いた 3 層構造がとても有効であ り，そのポイントは漏れ出る髄液圧を利用して再建することである。特に1枚目の大腿筋膜を硬膜内 に適度な大きさで，且つ適切な位置に敷き入れることだと考えている。敷き入れる筋膜のサイズは， 欠損の1.5 2 倍程度の前後・左右径とし, 硬膜の切除縁に筋膜を均等に留置しなければならない。敷 き込む筋膜の中央にピオクタニンで印を付け，偏ることなく敷き入れる。フィブリン糊で固定をする が，欲張って大量の糊を使用しすぎると2枚目，3枚目の敷き入れが上手く行かなくなるので注意する。 硬膜再建をマスターすれば，腫瘍病変だけではなく，副鼻腔炎手術において偶発的に生じてしまった 髄液漏にも対応できるようになるので, 鼻科手術を行う者はマスターすべき手技の一つと考えている。 細かい留意点も含め解説する。 